\title{
HUBUNGAN PERAN SERTA ORANG TUA DENGAN DAMPAK HOSPITALISASI PADA ANAK USIA PRASEKOLAH DI RUANGAN SANTA THERESIA RUMAH SAKIT SANTA ELISABETH MEDAN 2015
}

\author{
Samfriati Sinurat* \\ Staf Pengajar STIKes Santa Elisabeth Medan
}

\begin{abstract}
Background: The hospitalization is a full of stress experience both for children and for parents. The intervention of parent is needed to minimize the impact of hospitalization.

Goal: this study aimed to analyze the relationship between the intervention of the parents and the impact of hospitalization on children of preschool-age who were treated in kid room of Saint Theresa Saint Elizabeth Hospital Medan.

Method:The method used in this research is descriptive analytic research with cross sectional approach, the total sample were 40 people were taken by purposive sampling technique. The data were collected using questionnaires intervention of parents and the impact of hospitalization compiled by Abdulbaki (2011) and later modified by the researcher, then re-tested for validity and reliability. The study was conducted early August until the end of October 2015. Result:The results of the analysis using Chi Square Test showed statistically significant correlation between the participation of parents with the impact of hospitalization on preschoolers with value 0:02 $p$ values $(p<0.05)$. This study founded $62.5 \%$ the intervention of parents was good and $60 \%$ of hospitalization impact on preschoolers was light.

Conclusion:This study provides information that parents need to enhance their intervention of parents in caring for preschool children in order to minimize the impact of hospitalization on children.
\end{abstract}

Keywords: The Role of Parents, the Impact of Hospitalization, Preschoolers.

\section{PENDAHULUAN}

Hospitalisasi merupakan keadaan dimana orang sakit berada pada lingkungan rumah sakit untuk mendapat pengobatan sehingga dapat mengatasi atau meringankan penyakitnya. Pada umumnya hospitalisasi dapat menimbulkan dampak pada lima aspek, yaitu privasi, gaya hidup, otonomi diri, peran dan ekonomi (Asmadi, 2014).

Hospitalisasi pada pasien anak dapat menyebabkan kecemasan dan stres. Penyebab dari kecemasan dipengaruhi oleh banyak faktor, baik faktor dari petugas kesehatan, lingkungan baru, maupun orang tua yang menunggu selama perawatan. Orang tua sering merasa cemas terhadap perkembangan keadaan anaknya, pengobatan, dan biaya perawatan. Meskipun dampak tersebut tidak secara langsung kepada anak, secara pisikologis anak akan merasakan perubahan perilaku dari orang tua yang menungguinya 
selama perawatan. (Susilaningrum, dkk, 2013).

Anak yang dirawat dirumah sakit juga mengalami agresi, bentuk agresi tersebut tercermin dalam keinginan untuk dekat dengan orang tua, menangis merintih, menendang, memukul dan melarikan diri atau lebih serius penolakan untuk makan. Sakit dan hospitalisasi menimbulkan krisis pada kehidupan anak. Di rumah sakit anak harus menghadapi lingkungan yang asing dan pemberi asuhan yang tidak dikenal. Sering kali anak mengalami prosedur yang menimbulkan nyeri, kehilangan kemandirian dan berbagai hal yang tidak diketahui. Interpretasi anak terhadap kejadian dan respon anak terhadap pengalaman selama di rumah sakit akan diasumsikan sebagai pengalaman yang kurang baik, secara tidak langsung akan mempengaruhi tingkat perkembangan anak. (Yuli Utami, 2014)

Anak usia prasekolah belum mampu mengenal, memahami dan mengatasi masalah yang dihadapinya. Perawatan anak prasekolah dirumah sakit dapat menimbulkan dampak terhadap anak saat dirawat, ada berbagai kejadian selama anak dihospitalisasi yang menimbulkan stressor. Dampak hospitalisasi pada anak prasekolah saat dirawat dirumah sakit dapat dilihat dari perilaku anak tersebut diantaranya adalah penolakan terhadap suatu tindakan, menghindar dari situasi yang membuatnya tertekan dan bersikap tidak kooperatif terhadap petugas (Nursalam, 2011). Dampak hospitalisasi secara umum pada anak prasekolah yang dirawat di rumah sakit yaitu cemas terhadap perpisahan, kehilangan kontrol, luka pada tubuh dan rasa nyeri. Maka keterlibatan orang tua senantiasa dibutuhkan untuk mendampingi anak, memberi dukungan secara fisik maupun emosional. (Susilaningrum, 2013)

Hasil penelitian Yuli Utami (2014) tentang dampak hospitalisasi terhadap perkembangan anak menunjukkan bahwa anak prasekolah yang dirawat di rumah sakit masih sering mengalami stres rawat inap yang berat khususnya takut pada pengobatan, asing dengan lingkungan baru, dan takut terhadap petugas kasehatan. Dan penelitian yang dilakukan oleh weni Febrina (2014) tentang dampak hospitalisasi pada anak prasekolah menunjukkan bahwa anak prasekolah mengalami dampak hospitalisasi cemas berat sebanyak 53,6\%, Dan didukung oleh hasil penelitian yang dilakukan oleh Eko susilo (2013) di RSUD Semarang $58,8 \%$ mengalami kecemasan akibat hospitalisasi.

Menurut Harmoko (2012) peran orang tua sebagai perawat, pendidik, pendorong, pengawas, pencari nafkah dan pendamai. Dan Menurut Sri Utami (2013) menyatakan peran orang tua selama anak menjalani perawatan di rumah sakit adalah memberi dukungan social dan menjalin kerjasama dengan perawat. Anak prasekolah yang dirawat di rumah sakit akan merasa nyaman selama perawatan dengan adanya dukungan social keluarga, lingkungan perawatan yang teraupetik, dan sikap perawat yang penuh dengan perhatian.

Pengalaman orang tua ketika anak harus dirawat dirumah sakit 
merupakan pengalaman yang menegangkan. Hal tersebut terjadi karena ada perubahan peran orang tua ketika anak harus dirawat tenaga kesehatan di lingkungan rumah sakit dimana orang tua perlu memberi dukungan pada anak yang dirawat dan memperhatikan keluarga lainnya yang ada di rumah. Orang tua biasa mengalami stress akibat kondisi anak selama perawatan di rumah sakit. Pengalaman stres yang terjadi pada orang tua diakibatkan karena belum dapat informasi atau kurangnya informasi tentang kondisi anak, rencana pengobatan dan pemeriksaan diagnostic (Asmadi, 2014).

Penelitian yang dilakukan Winarsih Dwi (2012) tentang hubungan peran serta orang tua dengan dampak hospitalisasi pada anak usia prasekolah di RSU RA. Kartini Jepara menyatakan bahwa peran serta orang tua dalam perawatan membuat anak mampu mengembangkan diri secara pribadi dan memberikan sikap positif orang tua sehingga perawatan pada anak lebih optimal.

Dari hasil penelitian Kristiani (2014) dikatakan bahwa keterlibatan orang tua dalam perawatan anak prasekolah membantu meminimalkan dampak negatif dari hospitalisasi. Perawat disarankan untuk mampu meminimalkan dampak hospitalisasi pada anak prasekolah dengan memberikan terapi traumatic care.

Anak usia prasekolah yang dirawat di Rumah Sakit Santa Elisabeh Ruangan Anak Santa Theresia bulan Agustus sanpai Oktober sejumlah 50 orang anak. Anak usia prasekolah merupakan pasien anak yang terbanyak setiap tahunnya dibanding dengan usia bayi, toddler, maupun usia sekolah. Pengalama saya praktek di rumah sakit Santa Elisabet Medan ruang santa Theresia, hasil kajian selama 6 bulan tarkhir tahun 2015 bahwa dampak hospitalisasi pada anak usia prasekolah terlihat sangat jelas adanya penolakan dari anak saat akan dilakukan tindakan keperawatan kepada anak dengan respon rewel, menangis dan mengungkapkan ingin pulang.

Didukung oleh hasil wawancara dengan kepala ruangan dan perawat pelaksana mereka mengatakan bahwa pada umumnya anak prasekolah yang dirawat di rumah sakit Santa Elisabet Medan Ruangan Santa Theresia rewel, menangis dan minta pulang saat mau melakukan tindakan keperawatan. Perawat sudah melakukan berbagai upaya untuk meminimalkan dampak hospitalisasi dengan pemberian asuhan aktifitas bermain terhadap anak. Namun banyak orang tua yang kurang mendukung upaya yang telah dilakukan perawat hal ini dapat terlihat dari respon orang tua yang kurang sesuai yaitu, orang tua menenangkan dengan menakutnakuti pasien akan dilakukan hal-hal yang menyakiti anak yang mengakibatkan peningkatan ketakutan anak. Berdasarkan masalah diatas maka peneliti melakukan penelitian, tentang hubungan peran serta orang tua dengan dampak hospitalisasi pada anak usia prasekolak di ruang perawatan Santa Theresia Ruman Sakit Santa Elisabeth Medan tahun 2015. 


\section{METODE PENELITIAN}

Penelitian ini menggunakan rancangan penelitian deskriptif analitik dengan jenis cross sectional merupakan penelitian yang menekankan pada waktu pengukuran variable dependen dan independen hanya satu kali saja pada satu saat (Hidayat 2009). Penelitian ini dilakukan untuk mengukur dan mengamati bagaimana hubungan peran serta orang tua sebagai perawat, pendidik, pendorong dan pengawas dengan dampak hospitalisasi anak usia prasekolah di Rumah Sakit Santa Elisabet Medan tahun 2015.

Populasi adalah wilayah generalisasi yang terdiri atas: Objek/subjek yang mempunyai kualitas dan karakteristik tertentu yang ditetapkan oleh peneliti untuk dipelajari dan kemudian diterik kesimpulannya (sugiyono, 2013). Populasi dalam penelitian ini adalah orang tua yang menjaga anak usia prasekolah yang dirawat inap di Ruangan Santa Theresia Rumah Sakit Santa Elisabet Medan. Berdasarkan data dari rekam medis, jumlah pasien anak usia prasekolah pada bulan Agustus sampai Oktober 2015 sebanyak 50 orang.

Sampel terdiri atas bagian populasi yang terjangkau yang dapat dipergunakan sebagai subjek penelitian melalui sampling. Sampling adalah menyeleksi populasi yang dapat mewakili populasi yang ada (Nursalam 2013). Sampel adalah sebagian populasi yang diteliti. Teknik pengambilan sampel dilakukan dengan menggunakan purposive sampling yaitu suatu tehnik penetapan dengan cara memilih sampel diantara populasi sesuai dengan yang dikehendaki peneliti (tujuan/masalah dalam penelitian), sehingga sampel tersebut dapat mewakili karakteristik populasi yang telah dikenal sebelumnya (Nursalam, 2013).

Definisi operasional adalah mendefinisikan variabel secara operasional berdasarkan karakteristik yang diamati, sehingga memungkinkan peneliti untuk melakukan observasi atau pengukuran secara cermat terhadap suatu objek atau fenomena (Hidayat 2009).

\section{HASIL PENELITIAN DAN PEMBAHASAN}

Pada tabel 1 menunjukkan karakteristik responden, orang tua yang menjaga anak usia prasekolah yang dirawat semuanya adalah ibu sebanyak 40 orang (100\%). Sebagian besar responden berada pada kelompok umur 26-33 tahun sebanyak 19 orang (47.4\%) dan kelompok umur 34-40 tahun sebanyak 16 orang (40\%) sedangkan yang paling sedikit berada pada kelompok umur 41-47 tahun sebanyak 5 orang (12.5\%). Berdasarkan pendidikan orang tua mayoritas berpendidikan perguruan tinggi sebanyak 26 orang (65\%) dan yang terendah berpendidikan SMA sebanyak 14 orang (35\%). Pekerjaan responden terbanyak sebagai wiraswasta sebanyak 16 orang $(40 \%)$ dan yang paling sedikit sebesar 2 orang sebagai PNS. Berdasarkan pengalaman merawat sebanyak 31 orang $(77.5 \%)$ pernah merawat dan sebanyak 9 orang $(22.5 \%)$ tidak pernah merawat. 
Tabel 1. Distibusi Frekuensi

Dan Presentase Berdasarkan Karakteristik Responden Di Ruangan Anak Santa Theresia Rumah Sakit Santa Elisabeth Medan Bulan Agustus-Oktober 2015

\begin{tabular}{|c|c|c|}
\hline Data demografi & $\mathbf{f}$ & $\%$ \\
\hline \multicolumn{3}{|l|}{ Orang tua } \\
\hline Ayah & - & - \\
\hline Ibu & 40 & 100 \\
\hline Total & 40 & 100 \\
\hline \multicolumn{3}{|l|}{ Usia orang tua } \\
\hline 26-33 Tahun & 19 & 47.4 \\
\hline 34-40 Tahun & 16 & 40 \\
\hline 41-47 Tahun & 5 & 12.5 \\
\hline Total & 40 & 100 \\
\hline \multicolumn{3}{|l|}{ Pendidikan Orang tua } \\
\hline SMA & 14 & 35 \\
\hline PT & 26 & 65 \\
\hline Total & 40 & 100 \\
\hline \multicolumn{3}{|l|}{ Pekerjaan orang tua } \\
\hline Tidak bekerja & 8 & 20 \\
\hline Wiraswasta & 16 & 40 \\
\hline Pegawai swasta & 9 & 22.5 \\
\hline PNS & 2 & 5 \\
\hline Lain-lain & 5 & 12.5 \\
\hline Total & 40 & 100 \\
\hline \multicolumn{3}{|l|}{ Pengalaman merawat } \\
\hline Pernah & 9 & 22.5 \\
\hline \multicolumn{3}{|l|}{ Tidak pernah } \\
\hline Total & 45 & 100 \\
\hline
\end{tabular}

Tabel. 2. Distribusi Frekuensi Peran Serta Orang Tua Dalam Merawat Anak Di Ruangan Santa Theresia Rumah Sakit Santa Elisabeth Medan Bulan AgustusOktober 2015.

\begin{tabular}{lcc}
\hline $\begin{array}{l}\text { Peran serta orang } \\
\text { tua }\end{array}$ & f & \% \\
\hline Baik & 25 & 62,5 \\
Kurang baik & 15 & 37,5 \\
\hline \multicolumn{1}{c}{ Total } & $\mathbf{4 0}$ & $\mathbf{1 0 0}$ \\
\hline
\end{tabular}

Pada table 2 menunjukkan bahwa distribusi frekuensi peran serta orang tua dari 40 responden mayoritas sebanyak 25 orang $(62.5 \%)$ peran orang tua baik, dan sebanyak 15 orang $(37.5 \%)$ peran orang tua kurang baik.

Tabel 3. Distribusi Frekuensi Dampak Hospitalisasi Pada Anak Usia Prasekolah Yang Dirawat Di Ruangan Santa Theresia Rumah Sakit Santa Elisabeth Medan Bulan Agustus-Oktober 2015

\begin{tabular}{lcc}
\hline Dampak hospitalisasi & f & \% \\
\hline Ringan & 24 & 60 \\
Berat & 16 & 40 \\
\hline \multicolumn{1}{c}{ Total } & $\mathbf{4 0}$ & $\mathbf{1 0 0}$ \\
\hline
\end{tabular}

Pada tabel 3 menunjukkan bahwa distribusi frekuensi dampak hospitalisasi pada anak dari 40 responden mayoritas sebanyak 24 orang ( $60 \%$ ) dampak hospitalisasi pada anak ringan, dan sebanyak 16 orang $(40 \%)$ dampak hospitalisasi pada anak berat. 
Tabel. 4. Tabulasi Silang Hubungan Peran Serta Orang Tua Dengan Dampak Hospitalisasi Pada Anak Usia Prasekolah Yang Dirawat Di Ruangan Santa Theresia Rumah Sakit Santa Elisabeth Medan Bulan Agustus-Oktober 2015

\begin{tabular}{llllllllll}
\hline \multirow{2}{*}{$\begin{array}{c}\text { Peran serta } \\
\text { Orang tua }\end{array}$} & Ringan & & Berat & & Total & p & RP & $\begin{array}{c}\text { CI } \\
\text { 95\% }\end{array}$ \\
\hline & f & $\mathbf{\%}$ & $\mathbf{f}$ & $\mathbf{\%}$ & $\mathbf{f}$ & $\mathbf{\%}$ & & & \\
\hline Baik & 19 & 76 & 6 & 24 & 25 & 100 & 0,02 & 6,33 & $1,54-26$ \\
Kurang baik & 5 & 33,3 & 10 & 66.7 & 15 & 100 & & \\
\hline
\end{tabular}

Berdasarkan tabel 4 dapat diketahui hasil tabulasi silang antara peran orang tua dengan dampak hospitalisasi anak usia prasekolah di Rumah sakit santa Elisabeth Medan menunjukkan bahwa 25 responden yang peran serta orang tua baik ditemukan dampak hospitalisasi ringan sebanyak 19 orang $(76 \%)$ dan dampak hospitalisasi berat sebanyak 6 orang $(24 \%)$, kemudian dari 15 responden yang peran serta orang tua kurang baik ditemukan sebanyak 5 orang (33.3\%) dampak hospitalisasi rigan dan sebanyak 10 orang $(66,7 \%)$ dampak hospitalisasi berat.

Berdasarkan hasil uji chi square didapat $\mathrm{p}<0.05 \quad(\alpha=0.02)$ berarti ada hubungan yang bermakna secara statistic antara peran serta orang tua dengan dampak hospitalisasi anak usia prasekolah di ruangan Santa Theresia Rumah Sakit Santa Elisabet Medan. Peran orang tua 6.33 kali berpengaruh terhadap dampak hospitalisasi (CI 95\%: 1.5426).

\section{PEMBAHASAN \\ Peran serta orang tua}

Hasil penelitian peran serta orang tua dalam merawat anak yang dirawat diruangan Anak Santa Theresia Rumah Sakit Santa
Elisabeth Medan tahun 2015, menunjukkan bahwa distribusi frekuensi peran serta orang tua dari 40 responden ada sebanyak 25 orang (62.5\%) peran orang tua baik, dan sebanyak 15 orang $(37.5 \%)$ peran orang tua kurang baik.

Dari hasil penelitian ada sebanyak 15 orang (37.5\%) peran orang tua kurang baik dalam perawatan anak usia prasekolah di Ruangan Anak Santa Therasia Rumah sakit Santa Elisabeth Medan. Hal ini disebabkan oleh karena kurangnya pengetahuan orang tua dalam melakukan perannya sebagai perawat dalam mengompres anak saat demam dan kurang pengetahuan dalam melakukan peran sebagai pendidik dalam membaca cerita atau dongeng kepada anak, serta kurang pengetahuan dalam melakukan peran sebagai pendorong dalam memberi pujian kepada anak saat menghabiskan obat dan mengajak anak jalan-jalan disekitar rumah sakit jika anak bosan.

Menurut Harmoko (2012) peran adalah suatu tingkah laku yang diharapkan oleh orang lain terhadap seseorang sesuai kedudukannya dalam suatu system. Peran orang tua baik karena ada dukungan untuk memberi perawatan pada anak dalam 
hal merawat, mendidik, mendorong dan mengawas dari orang tua yang secara keseluruhan membuat anak lebih baik, dimana ketika anak dirawat di rumah sakit peran orang tua menjadi bertambah. Demikian pendapat (Asmadi, 2014) yang menyatakan ada perubahan peran orang tua ketika anak dirawat di lingkungan rumah sakit, dimana orang tua perlu memberi dukungan kepada anak yang dirawat dan memperhatikan keluarga lainnya yang ada di rumah.

Hasil penelitian yang dilakukan oleh Dwi Winarsih (2012) menyatakan bahwa peran orang tua yang merawat anak usia prasekolah di RSU RA. Kartini Jepara mayoritas berperan baik karena orang tua dilibatkan dalam proses asuhan keperawatan anak. Didukung hasil penelitian Ygge (2004) bahwa bentuk peran orang tua dalam perawatan anak di rumah sakit adalah keterlibatan orang tua dalam perawatan. Bentuk keterlibatan orang tua mulai dari komunikasi antara anak dan perawat, membantu dan mendampingi anak selama prosedur perawatan. Hal ini membuat anak merasa nyaman dan tidak takut menghadapi perawat atau dokter. Demikian juga hasil penelitian yang dilakukan oleh peneliti dengan adanya keterlibatan orang tua dan melakukan perannya dengan baik sehinga dampak hospitalisasi menjadi ringan.

Rumah sakit Santa Elisabet Medan Sudah melibatkan orang tua untuk berperan dalam perawatan anak yang bermanfaat untuk meminimalkan dampak hospitalisasi anak dan sudah tertulis dalam visi dan misi ruangan Anak Santa
Theresia Rumah sakit Santa Elisabet Medan yang menyatakan melibatkan keluarga dalam pemberian asuhan keperawatan. Terbukti dari hasil penelitian yang dilakukan oleh peneliti pada orang tua anak usia prasekolah yang dirawat diruangan Anak Santa Theresia Rumah sakit Santa Elisabeth Medan mayoritas baik, hal ini disebabkan oleh keterlibatan orang tua dalam merawat anak usia prasekolah, adanya dukungan dari rumah sakit untuk melibatkan orang tua dalam pemberian asuhan, kehadiran orang tua yang senantiasa mendampingi anak usia prasekolah yang sakit. Tetapi ditemukan juga ada peran orang tua kurang baik, hal ini disebabkan oleh karena kurangnya pemahaman orang tua tentang mengompres anak saat demam, manfaat membaca cerita atau dongeng kepada anak dan manfaat memberi pujian kepada anak saat menghabiskan obat, maka agar peran orang tua semakin baik perlu penyuluhan pendidikan kesehatan kepada orang tua tentang mengompres anak saat demam, menjelaskan manfaat bercerita untuk anak dan memberi dorongan kepada anak lewat pujian kalau anak minum obat dengan baik.

\section{Dampak hospitalisasi pada anak usia prasekolah}

Hasil penelitian dampak hospitalisasi pada anak usia prasekolah di ruangan Anak Santa Theresia Rumah sakit Santa Elisabeth Medan 2015, menunjukkan bahwa distribusi frekuensi dampak hospitalisasi pada anak sebanyak 24 orang ( $60 \%$ ) dampak hospitalisasi pada anak ringan, dan sebanyak 16 
orang (40\%) dampak hospitalisasi pada anak berat.

Dari hasil penelitian ada sebanyak 24 orang (60\%) dampak hospitalisasi pada anak usia prasekolah ringan, hal ini disebabkan oleh karena peran orang tua yang baik sehingga dampak hospitalisasi pada anak usia prasekolah tentang cemas akibat perpisahan hanya kadang-kadang saja dan dari hasil penelitian didapatkan bahwa kadangkadang saja anak menangis bila ditinggal orang tuanya, kadangkadang anak berteriak memanggil orang tuanya dan kadang-kadang anak menolak perawat saat dilakukan tindakan keperawatan. Dampak hospitalisasi pada anak usia prasekolah tentang kehilangan control hanya kadang-kadang saja, dari hasil penelitian didapat bahwa kadang-kadang saja anak menjerit saat dilakukan tindakan keperawatan, kadang-kadang anak memukul perawat atau dokter yang sedang memberi perawatan. Dampak hospitalisasi pada anak usia prasekolah tentang luka pada tubuh dan rasa nyeri mayoritas kadangkadang juga, dari hasil penelitian didapat kadang-kadang anak mengatupkan gigi dan bibir saat dipasang infus, dan mayoritas anak selalu aktif saat diajak bercerita.

Berdasarkan hasil penelitian ada sebanyak 16 orang $(40 \%)$ dampak hospitalisasi pada anak usia prasekolah berat. Hal ini disebabkan oleh karena masih ada peran orang tua yang kurang baik dalam merawat anak usia prasekolah sehingga ditemukan dari hasil penelitian bahwa ada anak selalu menginginkan ditunggui orang tuanya, selalu mencari orang tua saat diberi tindakan keperawatan dan anak selalu meringis kesakitan saat disuntik.

Dampak hospitalisasi pada anak usia prasekolah yang dirawat di ruangan Anak Santa Theresia Rumah sakit Santa Elisabeth Medan masih ada yang berdampak berat sebanyak 16 orang $(40 \%)$ hal ini sesuai dengan pendapat (Susilaningrum, dkk, 2013) yang menyatakan bahwa hospitalisasi adalah suatu keadaan krisis pada anak saat anak sakit dan dirawat di rumah sakit. Keadaan ini terjadi karena anak mengalami perubahan dari keadaan sehat dan rutinitas lingkungan serta mekanisme koping yang terbatas dalam menghadapi stressor. Stressor utama dalam hospitalisasi adalah perpisahan kehilangan kendali dan nyeri.

\section{Hubungan peran serta orang tua dengan dampak hospitalisasi pada anak usia prasekolah yang dirawat di ruangan Anak Santa Theresia Rumah Sakit Santa Elisabeth Medan 2015}

Berdasarkan uji statistic dengan menggunakan analisis chi square didapatkan dari 25 responden ada sebanyak 19 orang (76\%) peran orang tua baik dengan dampak hospitalisasinya ringan dan sebanyak 6 orang $(24 \%)$ peran orang tua baik dengan dampak hospitalisasi berat. Sedangkan dari 15 responden ada sebanyak 5 orang (33.3\%) peran orang tua kurang baik dengan dampak hospitalisasi ringan dan sebanyak 10 orang $(66.7 \%)$ peran orang tua kurang baik dengan dampak hospitalisasi berat. Berdasarkan uji chi square 
ditemukan nilai $\mathrm{p}$ volue 0.02 $(\mathrm{p}<0.05)$ secara statistic tedapat hubungan yang signifikan antara peran serta orang tua dengan dampak hospitalisasi anak usia prasekolah yang dirawat di ruangan Anak Santa Theresia Rumah sakit Santa Elisabeth Medan, hal ini disebabkan oleh karena adanya peran serta orang tua yang baik sehingga dampak hospitalisasi pada anak usia prasekolah ringan.

Hasil penelitian yang dilakukan oleh peneliti bahwa ada hubungan antara peran serta orang tua dengan dampak hospitalisasi anak usia prasekolah. Berdasarkan uji chi square ditemukan nilai $\mathrm{p}$ volue $0.02(\mathrm{p}<0.05)$ maka hipotesa yang digunakan Ha diterima bahwa ada hubungan peran serta orang tua dengan dampak hospitalisasi anak usia prasekolah yang dirawat di ruangan Anak Santa Theresia Rumah sakit Santa Elisabeth Medan. Peran serta orang tua 6.33 kali berpengaruh terhadap dampak hospitalisasi dengan confidence interval 1,54-26,0 terhadap dampak hospitalisasi pada anak usia prasekolah yang dipengaruhi oleh keterlibatan, kehadiran dan kasih sayang orang tua serta dukungan rumah sakit untuk melibatkan orang tua dalam perawatan anak usia prasekolah.

\section{Kesimpulan}

Berdasarkan hasil penelitian yang dilakukan di ruangan Santa Theresia Rumah Sakit Santa Elisabet Medan tentang peran serta orang tua dengan dampak hospitalisasi pada anak usia prasekolah dapat disimpulkan sebagai berikut:

Peran serta orang tua dalam merawat anak usia prasekolah di ruangan
Anak Santa Theresia Rumah sakit Santa Elisabet Medan tahun 2015 mayoritas berperan baik sebanyak 25 orang $(62.5 \%)$, namun perlu di perhatikan bahwa, ada peran orang tua kurang baik dalam hal mengompres anak saat demam dan membaca cerita atau dongeng kepada anak.

Dampak hospitalisasi pada anak usia prasekolah yang dirawat di ruangan Santa Theresia Rumah sakit Santa Elisabeth Medan tahun 2015 mayoritas berdampak ringan sebanyak 24 orang $(60 \%)$ dan berat sebanyak 16 orang $(40 \%)$.

Ada hubungan peran serta orang tua dengan dampak hospitalisasi pada anak usia prasekolah yang dirawat diruangan Santa Theresia Rumah Sakit santa Elisabeth Medan tahun $2015(\mathrm{p}=0,02<0,05)$.

\section{Saran}

Berdasarkan hasil analisa dan simpulan pada penelitian ini, maka saran yang bisa peneliti sampaikan adalah:

1. Bagi institusi Rumah Sakit Santa Elisabet Medan

Hendaknya tetap melibatkan orang tua dalam perawatan anak usia prasekolah untuk meminimalkan dampak hospitalisasi, sesuai dengan yang tertulis dalam palsafah,visi, misi ruangan Santa Theresia Rumah sakit Santa Elisabet Medan. Perlu penyuluhan pendidikan kesehatan kepada orang tua yang menjaga anak usia prasekolah yang sedang dirawat, dari hasil penelitian yang dilakukan oleh peneliti masih ada orang tua yang 
kurang mengerti tentang peran sebagai perawat dalam hal mengompres anak saat demam, mamfaat bercerita untuk anak yang sedang dirawat.

2. Bagi Institusi STIKes Santa Elisabeth Medan

Hasil penelitian ini dapat memberkan informasi dan menambah referensi tentang peran orang tua dan dampak hospitalisasi pada anak usia prasekolah.

3. Bagi peneliti selanjutnya

Hasil penelitian ini dapat digunakan sebagai bahan referensi untuk penelitian lanjutan dengan menggunakan desain penelitian yang berbeda dan juga dapat membandingkan dampak hospitalisasi anak dari tiap tingkat usia dan dari segi peran perawat dengan dampak hospitalisasi pada anak.

4. Bagi orang tua anak usia prasekolah

Perlu waktu dan pendampingan yang khusus dari orang tua untuk menjaga anak usia prasekolah yang dirawat sehingga anak merasa nyaman ketika dirawat di rumah sakit.

\section{DAFTAR PUSTAKA}

Abdulbaki, AM, dkk. 2011. Maternal versus pediatric nurse attitude regarding mothers participation in de care of their hospitalizet children. Jurnal of American science. Diakses 3 juli 2014
Andarmoyo, sulistyo, 2012. Konsep Teori, Proses dan Praktik Keperawatan. Yogyakarta: Graha Ilmu

Andarmoyo, Sulistyo, 2012. Keperawatan Keluarga; Konsep Teori, Proses, dan Praktek Keperawatan. Yogyakarta: Graha Ilmu

Apriany Dyan. 2013. Hubungan antara hospitalisasianak dengan tingkat kecemasan orang tua. keperawatan.unsoed.ac.id/sites/ default/files/jks 20130802_92104.pdf . Diakses 16 Juni 2015

Asmadi, 2014. Konsep dasar Keperawatan. Jakarta: EGC

Aziz Alimun Hidayat. 2009. Metode penelitian keperawatan dan teknik analisis data, Jakarta. Salemba Medika

Constantin, 2012. What is the role of parent, http://lifetcho.com. diakses 3 Juli 2014

Coyne, I 2006. Childrens experience of hospitalization, jurnal of child health care. Diakses 3 juli 2014.

Efendi dan makhfudli. 2013. Keperawatan Kesehatan Komunitas Teori dan Praktik dalam Keperawatan. Jakarta: Salemba medika

Friedman. MM. 2010. Buku ajar kererawatan keluarga: riset, teori dan aplikasi, edisi bahasa Indonesia. Jakarta: ECG 
Harmoko, 2012. Asuhan Keperawatan . Yogyakarta: pustaka Belajar

Kristiani Fera, Peran orang tua terhadap dampak hospitalisasi pada anak usia prasekolah, http://digilid.esaunggulan.ac.id , diakses 3 Juli 2014.

Lemeshow Stanley.1997. Besar sampel dalam penelitian kesehatan. Yogyakarta: Gadjah Mada University press.

Lumiu Stella Engel, hubunhan dukungan keluarga dengan tingkat kecemasan akibat hospitalisasi pada anak usia prasekolah Manado. https://skripsistikes.files.wordpr ess.com/2009/08/4.pdf,diakses 3 Juli 2014.

Murni asin dan Rahmawati andhika, Hubungan dukungan keluarga dengan tingkat kecemasan akibat hospitalisasi pada anak usia prasekolah di RSUD Klaten, http://www.skrisistikes.wordpres s.com, diakses 18 Juli 2014.

Nurcholis Ivan Syah, hubungan dukungan keluarga denga reaksi regresi anak prasekolah saat proseh hospitalisasi,https://skripsistikes .files.wordpress. com/2009/08/4.pdf, diakses 4 Juli 2015.

Nursalam, 2013. Metode Penelitian Ilmu Keperawatan. Jakarta: Salemba medika
Padila, 2012. Keperawatan Keluarga. Yogyakarta: Nuha Medika

Sopiyudin, 2012. Statistik untuk Kedokteran dan Kesehatan. Jakarta: Salemba Medika

Sugiono, 2010. Metode Penelitian Kuantitatif Kualitatif dan $R \& D$. Bandung: Alfabeta

Supartini, Y. 2004. Buku ajar konsep dasar keperawatan anak. Jakarta EGC

Susanto Tantut, 2012. Buku Ajar Keparawatan Keluarga. Jakarta: TIM

Susilaningrum, Nursala dan Utami, 2013.Asuhan Keperawatan Bayi dan Anak. Jakarta: Salemba Medika

Winarsih Dwi, 2012. Hubungan peran serta orang tua dengan dampak hospitalisasi anak prasekolah di RSU kartika Jepra. Lib.ui. ac.id/file=digital/\%20hubungan \%20peran.pdf. Diakses 16 Juni 2015

Wong,Marylin, 2007. Buku Ajar Keperawatan Pediatrik, Jakarta: EGC

Yasinta dan Yohanes. 2013. Asuhan Keperawatan Keluarga Konsep dan Praktik. Yogyakarta:Nuha Medika

Ygge. MB. (2004). Parental involumen in pediatric care implication for clinical practice 
and quality of care. Diaskes 16 juli 2015

Yuli Utam, 2014. Dampak hospitalisasi terhadap perkembangan anak. Online. http://dounload.portalgaruda.org /article.php?article $=\operatorname{dampak} \% 20$ hospitalisasi\%20terhadap\%20pe rkembangan\%20anak. Diakses 16 Juni 2015 